\title{
Court Interpreter Training at the Crossroads: Challenges and Future Prospects for Zimbabwe
}

\author{
(Mr.) Paul Svongoro \\ University of the Witwatersrand, South Africa \\ Email:604684@students.wits.ac.za/psvongoro@yahoo.com
}

\section{Doi:10.5901/mjss.2016.v7n2p106}

\section{Abstract}

\begin{abstract}
Zimbabwe's National Language Policy (1998) and The Constitution of the Republic of Zimbabwe (Amendment No. 20 of 2013) safeguard linguistic human rights and are both very clear on the need for the provision of court interpreters where the accused/complainant is not familiar with the language of the courts of law, namely English. Although significant strides have been made towards fulfilling this constitutional requirement by ensuring that all courts provide interpreters as and when required, the effort has not been supported by either the availability of a properly designed curriculum to ensure the availability of qualified interpreters or by the existence of a professional association, which could ensure that there is a professional code of ethics to which members must adhere or face sanction. This situation does not augur well for the practical intentions of court interpreting, particularly those aspects to do with the quality of court interpreting in Zimbabwe. It is against this background that court interpreting remains a contested area, with interpreters on several occasions being accused of misrepresentations and misinterpretations. This paper therefore explores the challenges Zimbabwe is facing in interpreter training and the prospects that lie ahead for the future. The paper argues that instead of procrastinating, Zimbabwe should consider trends and developments in court interpreting in different parts of the world, tailor-make them according to her needs and resources and move forward. This will be a giant step towards making sure that the rights of the linguistically handicapped with regard to the use of the language of the courts, namely English, are handled cautiously.
\end{abstract}

Keywords: linguistic human rights, court interpreter training, misrepresentations, misinterpretations

\section{A Brief Survey of Court Interpreting in Zimbabwe}

Zimbabwe's sociolinguistic profile can be described as being multilingual. The language of the former British colonisers i.e. English enjoys the status of the official language while Shona and Ndebele are the dominant languages in their respective geographic areas. Besides Shona and Ndebele, Hachipola (1998) in Viriri (2003) mentions a few other African languages: Kalanga, Nambya, Tonga, Venda, Tsonga, Nyanja and Tswana. Shona is widely spoken across the country by $75 \%$ of the population, and Ndebele by about $16 \%$ (Viriri 2003). This is probably the reason that Lodhi (1993: 83) lists Zimbabwe among the countries with one predominant African language. Although Zimbabwe is said to have the highest literacy rate in the SADC, some Zimbabweans are illiterate and cannot communicate in English. Many do not have the level of proficiency in English required in a sensitive communication setting such as the courtroom. To ensure that the linguistic rights of such persons are protected, interpreters are provided for Shona and Ndebele in court.

As alluded to by Svongoro \& Kadenge (2015), very little material exists on the historical background of court interpreting in Zimbabwe. This means that information on the subject is largely based on oral communication with various court stakeholders like chief and senior interpreters in Zimbabwe. The oldest of these interpreters has been employed for almost 44 years. The first interpreters in Zimbabwe, then Southern Rhodesia, were brought in from South Africa by the first white settlers in the nineteenth century. The interpreter's duties were those of a clerk, and he therefore had to be able to read and write. Hale (2004a) reports the same situation in Malaysia, where the courts requires them to act as court clerks, ushers, clerical staff and even lawyers with no training at all. Being exposed at times to working conditions such as these can affect on the interpreters' work. Since a Western kind of education was not yet available in Southern Rhodesia, i.e. a system which taught people the necessary skills, these interpreters had to be brought in from South Africa, even though at that time proper training for interpreters was not yet available in South Africa either, only commencing in the late 1990s (Moeketsi \& Wallmach 2005).

Svongoro \& Kadenge (2015) note that when western education in Southern Rhodesia was introduced, a select few, educated to Standard 3 or 4 (equivalent to today's Grades 4 and 5), would be employed as clerks with the Department of Native Affairs. These clerks were picked quite randomly, as the Department of Native Affairs was not too 
particular about their standard of education. The situation I report here is similar to what obtained in South Africa before 1994 (Moeketsi \& Wallmach 2005) and other African countries in which colonial languages dominated in all administrative and legal functions. In South Africa, for instance, as Moeketsi and Wallmach (2005) observe, English and Afrikaans are the languages of the courts of law, yet the majority of cases (about 90\%) involve speakers of the indigenous languages. In the past, as observed by Moeketsi (1999), court interpreters in the South African law courts were compelled to serve under judges and magistrates, who were agents of the apartheid regime and thus would neither concern themselves about the proper training of court interpreters nor encourage any improvement in their working conditions. Hoffmann (in the mid-twentieth century) introduced certain requirements, such as a working knowledge of Shona, Ndebele and Chewa. The interpreters were all black Africans, as the white settlers did not have sufficient knowledge of the local languages. In 1970 the majority of the interpreters in Salisbury (Harare) were black, two were white (Hoffmann and du Plooy) and one was coloured. Until 1981 all interpreters were also men, as it was believed that some jobs could not be performed by women.

The clerks-cum-interpreters were highly regarded by the black population, because they knew the white man's language and moreover understood the white man's law. Even when education became more widespread, these language mediators were still powerful because of their knowledge of legal terminology. Lang (1976) describes a similar situation in Papua New Guinea.

When criminal law courts were established, interpreting became a 'profession' in itself, and a list of guidelines for people wanting to be interpreters was gradually developed. Today's guidelines [as cited in the Ministry of Judicial, Legal and Parliamentary Affairs' regulations] state that anyone who intends to become an interpreter should possess at least five $\mathrm{O}$ Levels of at least $\mathrm{C}$ or better and at least 2 A Levels. In addition, the applicant must be proficient in English and at least two of the following languages, with a working knowledge of the third: Shona, Ndebele, or Chewa.

Again, as Svongoro \& Kadenge (2015) observe, the language qualifications are in actual fact not as strict as reflected above, as applicants with knowledge of other languages spoken in Zimbabwe such as Kalanga and Venda are also accepted. Somebody employed as an interpreter usually has no college or university qualification, as this is not a precondition. New candidates are tested by the Chief Interpreter, using self-devised tests. The recruits then receive onthe-job training from senior interpreters. In addition, the interpreters make use of two handbooks: A Guide to Interpreting in Judicial Proceedings (Hoffmann 1994) and Phrasebooks for Interpreters (Feltoe 1993), which are available in three languages: Shona, Ndebele and Nyanja.

The initial phase of the training programme is a test of candidates' language knowledge involving lists of English legal terminology. Candidates are required to give the Shona and Chewa equivalents. One can question the sincerity of such a training programme given the daily realities and conditions of interpreters' work (Giles 1995). Hale (2004a) points out these court interpreters need an extended training programme that enlightens them about the different spheres in which they do their work (Moeketsi 1999). Candidates who pass this phase proceed to the Induction Phase. They are taken to magistrate's courts to acquaint themselves with the various courts and the procedures that take place in them. This will also involve observing real court proceedings.

The candidates will then be brought before a dummy or mock court. Senior interpreters act out the roles of the magistrate, prosecutor, defence counsel, accused and witnesses and the new interpreter acts the interpreter's role. They use real court records that have already been processed, with the chief interpreter noting the performance of the interpreter and later on correcting any mistakes, verbal and non-verbal. This means that the interpreters do a lot within and outside their jurisdiction. Research has shown that interpreters who receive this kind of training are more likely to fail to give accurate renditions when they do not understand a message or the discourse of the utterance (Takimoto \& Koshiba 2009, Buenker \& Teichman 2005). What is needed are explicit standards in the field and specialised training for interpreters, especially considering that interpreters in Zimbabwe are not made aware in advance of the type of lawsuit and the potential lines of questioning. Buenker \& Teichman (2005) observed that, if court interpreters were made aware in advance of cases in which they are to interpret it would alleviate some of the potential stress of encountering unexpected vocabulary or unfamiliar participants.

Normally, it takes six months for a new interpreter to be 'properly' trained in Zimbabwe; it used to take a meagre six-week orientation period provided by the Judiciary College in South Africa before 1994 (Moeketsi 1999). Once the trainee interpreter has managed the dummy court, he/she is taken to a plea court and thereafter goes to the trial courts. After six months, or sometimes sooner depending on how fast the new interpreter learns, he/she will be assessed by the chief interpreter and if all has gone well he/she will be able to work in the courts on their own. However, it is important to note that what obtains in Zimbabwe today is what other countries have gone through and have started correcting. South Africa (Moeketsi \& Wallmach 2005, Wallmach 2004), Australia (Hale 2004b) and the United States of America (Freedgood 2010) are good examples. 
This is the procedure that is followed in the training of court interpreters in Zimbabwe under normal circumstances. Although it may not be ideal or adequate, given the fact that it is not a training programme resulting in a professional title, at least the new interpreter is not totally unprepared when they face real court interpreting. However, most of the junior interpreters employed at the magistrate's courts in Zimbabwe today went through a crash course in May 2000, owing to a serious shortage of interpreters, thus not receiving the usual six months of training.

\section{The Problem}

Despite the numerous challenges that face court interpreting as a profession in Zimbabwe, there is a dearth of pertinent studies on the nature of court interpreting in Zimbabwe. A short paper by Dube (1997) and an unpublished MA dissertation by Van Grieken (2001) remain the notable contributions in this area. However, none of these studies delve into issues pertaining to the skills required in interpreting or to the training of court interpreters in Zimbabwe. Court interpreters in the country are none the less often accused of being inconsistent and inaccurate during criminal trials. An article that appeared in the Daily News of 9 March 2001 titled 'Lawyer walks out of court over interpreter' and another in The Herald of 16 January 2008 titled 'Court Interpreters should be well paid' are typical examples.

Peripheral findings from cases studied by Van Grieken (2001) reveal huge interpreting shifts and many sorts of interpreter misinterpretation/misrepresentations. This means that instances of inaccuracy, a lack of proficiency and general incompetence characterise the service. This situation contradicts the aim of interpreting, which is to enable communication in such a way that the presiding officer is able to adjudicate in the matter between the prosecution and defence (Gonzalez et al 1991: 294; De Jongh 1992). According to Moeketsi's (2000: 227) summary on court interpreting, 'Court interpreting should allow the accused person or any other party who does not speak the language of the court to participate effectively in the case that concerns them as though the proceedings were conducted in their own language.' This implies that the interpreter as an officer of the court is a pivotal role-player in the proceedings.

This paper is essentially a review of court interpreting in Zimbabwe. It aims at tracing and reviewing the development of the practice and profession of interpreting in Zimbabwe. The paper also looks at the challenges the profession faces and the prospects that lie ahead.

\section{Justification}

One of the results of colonialism is that there are two legal systems in Zimbabwe. Customary law as practised by the traditional chiefs is a continuation of the law practised in Zimbabwe before colonialism. Criminal law, as practised for instance in the magistrate's courts, is a legacy of the colonial era, introduced by the British. While customary law is practised in the language of the chief and his people, criminal law is practised in the language of the former coloniser, i.e. English. The Report on the Formulation of a National Language Policy (1998: 25) states that in the Constitution of Zimbabwe (Articles 82 and 87):

There is recognition of the convention that in Zimbabwe law is practised in English ... The only concessions allowed are to be found in Articles 13 and 18 of the Constitution, which state that a person who is arrested or detained shall have his or her charge or reason of detention explained 'in a language that he understands' [Articles 13 and 18(3)(b)] and shall be permitted to have without payment the assistance of an interpreter if he cannot understand the language used at the trial, that is, English [Article 18(3)(f)].

According to the same report as Svongoro \& Kadenge (2015) observe, more than 98\% of the population of Zimbabwe speak one or more African language(s) as their mother tongue. For the vast majority, English is learned formally in schools and remains a second language. Even for those who speak English fluently, or with near fluency, the technicality of legal English, and the specialised use of ordinary terms, causes great obstacles to communication in the courts of law. This makes the use of an interpreter a necessity in the majority of cases. Hoffman (1994), echoed by Feltoe (1993: 56), stress the importance of the interpreter in the courts:

As the pivot of the court, the interpreter bears a heavy responsibility in the administration of justice, because upon him depends, to a great degree, the proper elucidation of the issues, thereby avoiding a miscarriage of justice, i.e. upon his word may depend the liberty, reputation or, at times, the very lives of the accused persons (Hoffmann 1994: 1).

As can be understood from this, interpreting is an integral part of courtroom communication. And if the interpreter makes mistakes, whether these are omissions, additions or replacements (cf. Dube (1997) and Lang (1976), this may have serious consequences for the delivery of justice.

Despite the importance of court interpreting as part of courtroom communication, and the importance that is attached to correct interpretations, and despite the fact that interpreters do not have qualifications beyond secondary 
school, no comprehensive study on courtroom interpreting in Zimbabwe has, to my knowledge, been carried out. There exists a short paper presented by Dube at the 1997 LSP symposium in Italy. The paper shows that there are huge differences between the proposed message of the source language $(\mathrm{SL})$ and the interpreted message in the target language (TL). I believe that the findings of this short paper call for a more comprehensive, in-depth analysis of the issues that are raised in it.

I believe this is especially important because studies carried out on court interpreting and on communication through the medium of a language other than the mother tongue (of the accused or witness) show that there are discrepancies between what was said and what was meant, i.e. the intended message was not communicated appropriately. For instance, research projects carried out at the University of Oslo have shown that professionally trained interpreters may make mistakes that could jeopardise the rights of the individual to a fair trial owing to mis- or noncommunication.

As mentioned before, court interpreting is still an understudied area in Zimbabwe. This means that the role of linguistics in analysing courtroom discourse has not been an object of serious systematic study in the Zimbabwean context. Yet, despite the close connection and importance of language to law, local linguists have not paid much attention to it. Perhaps studies by Dube (1997), Van Grieken (2001) and Svongoro (2007) make a worthwhile endeavour to place the subject in a Zimbabwean context. However, much of what is written in these studies is of a prescriptive and descriptive nature and rarely based on empirical courtroom evidence. It is against this paucity of research that the author sees the need for a review of interpreting in Zimbabwean courtrooms.

Despite the importance of courtroom interpreting, there seems to be a glaring inconsistency when one considers the quality of training court interpreters receive in Zimbabwe. Although training of court interpreters has become more widespread in different parts of the world (Hale 2004), in Zimbabwe pre-service college training is still not a requirement for interpreters. The majority of interpreters working in Zimbabwean courtrooms remain untrained bilinguals, yet interpreting tasks require a very high level of not only bilingualism but also biculturalism and adequate training and practice (Hale 2004). If interpreters are not college trained, they will not be regarded as professionals and hence will have no credibility among other professionals like lawyers, magistrates and judges. Untrained interpreters, as Hale (2004) observes, will also generally have a poor understanding of the complexities of the interpreting process, of the significance of the task and of the implications of their choices, which will in turn make them insecure and vulnerable to pressures. Giles' (2009) Efforts Model presents the Tightrope Hypothesis in attempting to show some of the psychological pressures interpreters face in the course of their work. The Tightrope Hypothesis states that problems occur in interpreting when total processing capacity requirements exceed available processing capacity, and when processing capacity available for a given effort is not sufficient for the task the interpreter is engaged in at a given time. The model therefore provides conceptual ground to fully understand interpreting processes for maximum interpreter training effect. Through his current study, the researcher hopes to obtain authentic evidence to raise awareness of the issue of training for interpreters in Zimbabwe, so that they are better prepared for their work.

Jacobsen (2002) points out that court interpreters the world over are often accused of misinterpreting, and misrepresenting, what the accused and witnesses say, which may result in incorrect decisions being made (Hale 2004a, Keratsa 2005, Moeketsi 1999, Lee 2009, Berk-Seligson 1999, Freedgood 2010, etc). In Zimbabwe, for instance, there have been allegations that the interpreters misrepresent what the accused and/or witness is saying in Shona, as reported in The Herald and the Daily News articles cited above. There is therefore a need to carry out a linguistic investigation into the different ways in which interpreters give their renditions in the course of their work and the effects they have on the legal process. It is hoped that issues raised in this paper will enlighten the practice of interpreting, promote the need for specialist court interpreting training and help develop appropriate curricula based on data-based research.

In the context of the current reality of court interpreting in Zimbabwe, this paper aims to stimulate discussion on issues relating to the knowledge about the practice and profession of interpreting in general and court interpreting in particular. It is therefore hoped that the issues raised in this paper will be of interest for those interested in practical interpreter training, developing and maintaining their interpreting skills and ensuring world-class continuous training.

\section{Insights from Court Interpreting Research}

The past two decades saw an increasing scholarly interest in court interpreting in different parts of the world although very few have emerged from Zimbabwe (Moeketsi 1999; Mikkelson 1999; Hale 2004; Lebese 2013; \& Svongoro 2015). Court interpreting is sometimes regarded as belonging within the broader concept of what is usually termed community interpreting (Roberts 1997) or more professionally as public service interpreting (PSI) (Valero-Garcés 2005). According to Roberts (1997: 8), the terms ad hoc interpreting, cultural interpreting and liaison interpreting are sometimes used as 
synonyms for this activity. However judging from the occurrence of these terms in the literature, community interpreting and public service interpreting have now become the most widely accepted labels. Although court interpreting is considered under the broader field of community interpretation, Pöchhacker (1999: 127) observes that, more often than not, court interpreting "is viewed as a separate specialty", one that is distinct from the activity of public service interpreting. The same activity mentioned here as court interpreting is occasionally referred to as legal interpreting, judiciary interpreting or forensic interpreting. Most interpreting scholars however, prefer the term court interpreting (e.g. Berk-Seligson 1988, 1990; Hale \& Luzardo 1997; Mikkelson 1998, 2000; Morris 1995; Roberts 1997). Strictly speaking, the term limits interpreting to a given setting, namely a court of law, but interpreting conducted in various other institutions associated with the judiciary, for example law offices, law enforcement agencies, and prisons, also tend to come under the heading of court interpreting (Mikkelson 2000).

In this paper, court interpreting is used to refer to all activities involving language mediation for people who do not speak the same language to facilitate a trial in a court of law. Court interpreting is understood in Roy's (2000: 112) terms as, "a linguistic and social act of communication, and the interpreter's role in this process is an engaged one, directed by knowledge and understanding of the entire communicative situation, including fluency in the languages, competence in appropriate usage within each language, and in managing the cross-cultural flow of talk". In Zimbabwean courtrooms, where trials are based on the common-law tradition characterised by rapid questioning of witnesses, long consecutive interpreting is not feasible during examination and cross-examination, but could be used when interpreting witness and expert testimonies, and the pronouncement of the judgement.

Court interpreting is usually conducted in the short or sequential consecutive mode which operates at the sentence level and where "the interpreter must wait for the speaker to finish before beginning the interpretation" (Mikkelson 2000: 70). As a result, consecutive interpreting adds considerably to the length of the proceeding.

According to Angelelli (2004), most empirical studies on the role of the interpreter which emerged in the past two decades were conducted in one specific setting and were of a qualitative nature (e.g., ethnographies of communication or discourse analysis studies). Berk-Seligson (1990) for instance, explored the participatory role of the interpreter in her ethnography of a courtroom. Berk-Seligson (1990) demonstrated that through manipulation of the use of polite forms among other sociolinguistic devices, interpreters in the bilingual courtroom become more or less visible. This phenomenon is also evident in descriptive studies such as those performed with witness statements at a police station (Fowler 1997) and in Danish (Jacobsen 2002) and Australian (Hale 2004) courtrooms.

In Zimbabwe, Van Grieken (2001), Svongoro (2015) and Svongoro and Kadenge (2015) focus on court interpreting as an area of liaison interpreting. The range of linguistic, cultural, pragmatic, historical and legal issues presented in these works offers a rich and alluring examination of the field of liaison interpreting. In her study, Van Grieken (2001: 58) examines interpreters' coping strategies in Zimbabwean courtrooms and argues that 'for most interpreter encounters, interpreting is much more than making cultural adjustments and changes to language structures, and as such, interpreted events should be treated as three-way/triadic interactions in which every participant's utterance impacts on other participants". Svongoro and Kadenge (2015) for instance, seem to concur with Van Grieken's (2001) study as both studies show that interpreter training or lack of it has been seen as having a direct impact on interpreter performance. In the case of Zimbabwe, it is not a case of complete neglect but a case of limited interpreter training and professional recognition, which raises a number of questions on the competence of the court interpreters to contend with the challenges posed by the interpreting task. Although the court interpreting profession is systematically structured in Zimbabwe according to a hierarchy similar to what obtains in South Africa (Moeketsi 1999), ranging from entry-level interpreters, senior interpreters, and principal interpreters and to chief interpreters, they are still held in low regard, and are even rated lower than legal clerks.

In Zimbabwe, like Lebese (2013) observed for South African court interpreters, court interpreters regularly find themselves performing tasks that are outside their scope of duties with some working as drivers and others performing clerical duties which in turn compromises their own work. According to an advert for court interpreters posted on the Judicial Service Commission of Zimbabwe website (2014), court interpreters also have counselling vulnerable litigants in the Victim Friendly Court, receipting bails, fines and paying out witness expenses listed as some of their duties.

Moreover, court interpreters in Zimbabwe are still fighting to be ranked fairly within the Judicial Service Commission. Unlike magistrates for instance, whose interests are represented by the Magistrates' Association of Zimbabwe (MAZ), there is still no professional association for court interpreters in Zimbabwe. The absence of any professional association which would be in a better position to engage and sensitise the government and other stakeholders in regard to the influential and important role court interpreters play in the administration of justice has meant that interpreters' issues, aspirations and working conditions remain unattended. At a meeting held with court interpreters at Mutare magistrates' courts on 28 February 2014, most junior interpreters confessed ignorance of the 
existence of any court interpreters' association. However, although most senior interpreters acknowledged the existence of the Zimbabwe Court Interpreters' Association, they admitted the association was inactive and faced collapse due to non-payment of subscriptions by members. The absence of an active court interpreters association runs contrary to Herbulot's (1998: 3) view that a professional association ensures that the professional status of interpreters in not undermined. When this status is clearly articulated, "it will take on reality in the eyes of others, instead of being considered merely as something anyone can do". The absence of an active association was also blamed by the interpreters at the same meeting for the non-availability of refresher workshops and training they used to have in the past with funding from such organizations as Lawyers for Human Rights, Legal Aid Project (LAP) and The Catholic Commission for Justice and Peace (CCJP). The interpreters at the meeting highlighted that such refresher workshops would have been even more relevant now in view of the changes made to the Criminal Procedure and Evidence Act (Chapter 9: 07) which is made reference to every day in court but which they are unfamiliar with. The absence of an active professional association was, as the interpreters at the meeting pointed out, the reason why their concerns about working conditions, preparation time and interpreter by-pass continue to be unresolved issues in their everyday life as interpreters in Zimbabwe. It is important for court interpreters to belong to a professional association (Keratsa 2005) which would be able to project the need for the services of their members, as well as the need to be treated professionally.

With the scenario presented above regarding professionalisation and accreditation of court interpreters in Zimbabwe, one wonders whether court interpreting can be regarded as a profession or not. According to Madhuku (2010: 84), a profession is only a profession when:

(1) It has a governing body with powers of control and discipline.

(2) There is some register or record of membership.

(3) There is restriction of admission to those with the required standard of special skills, education and training.

(4) There is voluntary submission by members to standards of ethical conduct beyond those required of the ordinary citizen by law.

(5) The duty to clients is paramount.

However, the court interpreting profession in Zimbabwe fails to meet most if not all the above benchmarks which leaves the profession open to the conclusion that "it is still a profession in the making" (Mikkelson, 2000: 47).

In spite of this evidence, many professional organisations in Zimbabwe and elsewhere today continue to state that interpreters are neutral, objective conduits who lack agency in the communicative event. When rules governing the work of an interpreter in a court of law are constructed, the complexity of a role such as the one studied by interpreting researchers is paradoxically presented as a controllable and automatic neutral position.

What emerges from the above is that a number of studies have been carried out on features characterising court interpreting and threats facing interpreting in bilingual courtrooms both outside and within Zimbabwe. Although language use in cases of alleged rape is slightly different, the studies cited above have contributed immensely to the development of this paper in different ways.

\section{Challenges Facing the Practice of Court Interpreting in Zimbabwe}

From the brief survey of court interpreting in Zimbabwe and other parts of the world presented above, one can safely draw the conclusion that court interpreting is not yet a recognised profession in Zimbabwe's judicial system. Chimhundu (1992: 38) attests to this and states: "In Zimbabwe, interpreting and translation is not regarded as a profession or a discipline for which one can study at a higher institution and then qualify to practice professionally." This explains why court interpreters in Zimbabwe continue to be regarded as general workers at the same level as clerical officers in the public service.

The major challenges in the absence of a properly developed translation and interpreting profession relate to:

a) a lack of training for professional interpreters, as pre-service qualifications are not a prerequisite;

b) the non-existence of accredited professional associations for practising interpreters to advance their interests and facilitate on-going training through seminars, workshops and conferences;

c) the absence of qualified interpreter trainers, as no college or institution to date offers training programmes in translation/interpreting.

In the absence of a recognised professional association the question of a code of professional ethics and conduct may not be handled appropriately. Moreover, codes of ethics provide a general definition of the aims of the profession. 


\section{Prospects for the Future}

The review of court interpreting in Zimbabwe has shown that although Zimbabwe still faces a number of challenges regarding the development of court interpreting into a fully recognised profession, it is developing in the right direction in terms of interpreter training. As alluded to before, court interpreters undergo six months of on-the-job training, which means that these interpreters are not totally unprepared for the important work they do. This progress, however, is slow and inadequate when compared with developments and trends in other parts of the world.

Zimbabwe's sociolinguistic fabric is far less complicated than one finds in most African countries. South Africa, Mozambique and Nigeria can be cited as some notable examples of African countries with complex language situations. With such a simple language environment, the country can easily catch up by establishing linkages with countries like South Africa, which are working tirelessly to make sure world-class interpreting services are provided at the same time as they ensure that the work of interpreters is recognised, more exciting and rewarding.

\section{Conclusion}

This paper explored the challenges Zimbabwe faces in interpreter training and the prospects that lie ahead for the future. The paper has shown that Zimbabwe continues to lag behind in terms of interpreter training, as there are still very few recognised university/college courses for interpreters. Both pre-service training and continuing education are relatively unknown. This scenario still persists in the country even though research in different parts of the world has shown that there are obvious performance differences between trained and untrained interpreters. Trained interpreters, for example, have been seen as better positioned to face the moral, ethical and psychological challenges of interpreting than their untrained counterparts.

Compared with other countries which are multicultural and multilingual (Australia, USA, Spain and South Africa to mention a few), the paper argues that instead of procrastinating, Zimbabwe should consider trends and developments in court interpreting in different parts of the world, tailor-make them according to her needs and resources and move forward. This will be a giant step towards making sure that the rights of the linguistically handicapped with regard to the use of the language of the courts, namely English, are handled cautiously.

The paper further argues that Zimbabwe should at least take comfort in the fact that its linguistic, and hence cultural fabric, is not as complex as in the above mentioned countries. English is its official language, and Shona and Ndebele are the dominant African languages in their respective geographic areas.

\section{References}

Angelelli, C. (2004). Revisiting the Interpreter's Role: A study of conference, court and medical Interpreters in Canada, Mexico and the United States. Amterdam \& Philadelphia: John Benjamins.

Berk-Seligson, S. (1988). The Impact of Politeness in Witness Testimony: The Influence of the Court Interpreter. Multilingua 7 (4) , 411 439.

Berk-Seligson, S. (1990). The Bilingual Courtroom: Court interpreters in the Judicial Process. Chicago: University of Chicago Press.

Berk-Seligson, S. (1999). Court interpreting in the USA: Recent development. In Lotriet, A (ed.). ActaVaria 1: 15.

Buenker, JF \& Teichman, DE. (2005). Revelations of a case style in a vehicular accident law suit. Translation Journal 9(3): 47-58.

Chimhundu, H. (1992). Translation, Media and Communication. Proceedings of the Third ASU Conference/Worksop. Maputo: LASU.

De Jongh, EM. (1992). An Introduction to Court Interpreting: Theory and Practice. Lanham: University Press of America.

Dube, CM. (1997). Multiple languages in a courtroom: Insights from a Zimbabwean experience. Paper presented at the LSP 99 Symposium, Italy.

Feltoe, G. (1993). Phrasebooks for Interpreters. Unpublished. Harare.

Fowler, Y. (1997). The Courtroom interpreter. Paragon and Intruder. In A. D. S.E. Carr, The Critical Link: Interpreters in the Community (pp. 191-200). Amsterdam \& Philadelphia: John Benjamins.

Freedgood, J. (2010). Pragmatic power of interpreters in trial testimony: A critical factor to bear in mind. Translation Journal 9(3): 11-17. Giles, D. (1995). Basic Concepts and Models for Interpreter and Translator Training. Amsterdam: John Benjamins.

Giles, D. (2009). Basic Concepts and Models for Interpreter and Translator Training (revised edition). Amsterdam and Philadelphia: John Benjamins.

Gonzalez, R.D, Vasquez, V.E \& Mikkelson, H. (1991). Fundamentals of Court Interpretation: Theory, Policy and Practice. Carolina: Carolina Academic Press.

Hachipola, S.J. (1998). A Survey of the Minority Languages of Zimbabwe. Harare: University of Zimbabwe Publishers.

Hale, S \& Luzardo, C. (1997). What am I expected to do? The Interpreter's ethical dilemma: A study of Arabic, Spanish and Vietnamese speakers. Antipodean The Australian Journal 1 (10) , 10-16. 
Hale, S. (2004a). The interpreter's identity crises. Paper presented at the first Conference of the International Association for Translation and Intercultural Studies: Translation and Construction of Identity, Seoul, South Korea, 11-14 August 2004.

Hale, S. (2004b). The Discourse of Court Interpreting: Discourse Practices of the Law, the Witness and the Interpreter. Amsterdam: John Benjamins.

Hale, S. (2005). How faithfully do court interpreters render the style of non- English-speaking witnesses' testimonies? A data-based study of Spanish-English bilingual proceedings. Discourse Studies 4(1): 25-47.

Hale, S \& Gibbons, J. (1999). Varying realities: Patterned changes in the interpreter's of courtroom and external realities. Applied Linguistics 20 (2).

Herbulot, F. (1998). The FIT Experience: The Role of Professional Translators' and Interpreters' Associations Towards Promoting the Interests of Language Workers. In K. W. A. Kruger, Language Facilitation and Development in Southern Africa. Pretoria: Blue Chip Printing Services.

Hoffman, J. (1994). A Guide to Interpreting in Judicial Proceedings. Harare: Government Printers.

Jacobsen, BN. (2002). Additions in court interpreting: A PhD project investigating the language of court interpreting in Danish courtrooms. Available at http://www.criticallink.org/journalsc12/5 (accessed 24 February 2012).

Jieun, L. (2009). Interpreting inexplicit language during courtroom examination. Applied Linguistics 30(1): 93-114.

Keratsa, A. (2005). Court interpreting: Features, conflicts and the future. Translatum Journal: 1-12.

Lang, R. (1976). Interpreters in local courts in Papua New Guinea. In O'Barr, WM \&

O'Barr, J.F (eds.). Language and Politics. The Hague: Mouton.

Lebese, S.J. (2013). The undefined role of Court interpreters in South Africa. University of South Africa: Unpublished MA Dissertation.

Lee, J. (2009). Interpreting inexplicit language during courtroom examination. Applied Linguistics 30(1): 93-114.

Lodhi, A.Y. (1993). The language situation in Africa today. Nordic Journal of African Studies 2(1): 79-86.

Madhuku, L. (2010). An Introduction to Zimbabwean Law. Harare: Weaver Press and Friedrich-Ebert-Stiftung.

Moeketsi, R. (1999). Discourse in a Multilingual and Multicultural Courtroom: A Court Interpreters' Guide. Pretoria: J.L van Schaik.

Moeketsi, R. (2000). The dos and don'ts in court interpreting: A functional approach to a professional code. Language Matters 31(1): 222-242.

Moeketsi, R \& Wallmach, K. (2005). From spaza to makoya!: A BA degree for court interpreters in South Africa. The International Journal of Speech, Language and the Law 12(1): 77-108.

Mikkelson, H. (1998). Towards a Redefinition of the Role of the Court Interpreter. Interpreting 3 (1) , 21-45.

Mikkelson, H. (1999). Court Interpreting at a Crossroads. NAJIT Conference.

Mikkelson, H. (2000). Introduction to Court Interpreting. Manchester and Northampton: St Jerome.

Morris, R. (1995). The Moral Dilemma of Court Interpreting. The Translator, (1) , 25-46.

Nord, C. (2003). Persons shall not be discriminated on account of language: Training interpreters for the community and the courtroom. Across Languages and Cultures 4(2): 253-264.

Pöchhacker, F.P. (1999). Getting Organized: The Evolution of Community Interpreting. Interpreting 4 (1) , 125-140.

Roberts, R.P. (1997). Community Interpreting Today and Tomorrow. In R. R. S.E. Carr, The Critical Link: Interpreters in the Community (pp. 7-26). Amsterdam \& Philadelphia: John Benjamins.

Roy, C.B. (2000). Interpreting as a Discourse Process. New York: Oxford.

Svongoro, P.R. (2007). An investigation into the linguistic features used in courtroom discourse by the court and ordinary persons in selected cases of alleged rape held at the Mutare Magistrates' Courts. Unpublished MA dissertation, University of Zimbabwe.

Svongoro, P \& Kadenge, M. (2015). From language to society: An analysis of interpreting quality and the rights of the accused in selected Zimbabwean courtrooms. South African Journal of African Languages, 33(1) , 47-62.

Svongoro, P. (2015). The impact of additions in Shona and English consecutively-interpeted rape trials in Zimbawean courtrooms. Per Linguam, 31 (1) , 105-120.

Takimoto, M \& Koshiba, K. (2009). Interpreter's non-rendition behaviour and its effects on interaction. The International Journal for Translation and Interpreting Research 1(1): 15-26.

Valero-Garcés, C. (2005). Emotional and Psychological Effects on Interpreters in Public Service. The Translation Journal 5 (3) , $106-119$.

Van Grieken, A.M. (2001). An investigation into the role and effectiveness of court interpreting. Unpublished MLSP dissertation, University of Zimbabwe.

Viriri, A. (2003). Language planning in Zimbabwe: The conservation and management of indigenous languages in Zimbabwe. Paper presented at ICOMOS, Victoria Falls, Zimbabwe.

Wallmach, K. (2004). Pressure players 'or 'choke artists'? How do Zulu simultaneous interpreters handle the pressure of interpreting in a legislative context? Language Matters 34: 179-200.

Wallmach, K. (2000). Examining simultaneous interpreting norms and strategies in a South African legislative context: A pilot corpus analysis. Language Matters 31: 198-221. 